\title{
体平衡と各種視運動性刺激の関係
}

$$
\text { 三 好 豊 二 }
$$

\section{Relationship between Body Sway and Several Optokinetic Stimuli}

\author{
Toyoji Miyoshi \\ (National Sanatrium Minami Kyoto Byoin)
}

The effects of optokinetic stimuli of several types upon body balance were discussed. A force plate for measuring the body center of gravity and a Jung-type optokinetic stimulator were used. A separating device for visual field was attached to create a condition of artificial scotoma. Optokinetic stimuli of the whole visual field, peripheral visual field and whole visual field with a fixating point were tested. The results were as follows.

1. The body sway induced by optokinetic stimulation of the whole visual field shows two phasic deviations. In the slow speed range of stimulation, the body deviates in the direction opposite to the rotation. In the high speed range, on the contrary, it deviates in the same direction as stimulation.

2. The former phase may be a coordinative one and the latter one a disturbed phase.

3. Body sway induced by peripheral optokinetic stimulation, whether looking or staring, shows one directional deviation, in the same direction as the stimulation.

4. The body is attracted to the same direction as the stimulation, when a fixating point is set on the screen of the optokinetic stimulator.

5. The states of these latter three conditions are quite similar to that of the second phase of the usual optokinetic stimulation, that is to say, the disturbed phase.

6. The disturbance of body balance of this kind arises from disoriantation in space due to the image slipping on the retina.

7. The subject who has been disturbed is attracted by stimulation and deviates toward the same direction as the stimulation.

\section{は じめに}

視覚が平衡維持に重要な役割を果すことはよく知られている。異常な視空間, 例えば遊園地によ く見られるミラクルハウスなどに入ると，一方向に強く引かれる様な異和感を感じると共に，姿勢 の変化を生じることが報告されている(2). 一方橋の上に立って川の流れを眺めていると, 憍が上流 の方向に動いて行く錯覚を生じる様な経験はしばしばあり，プラットホームに立っている時，眼前 を電車が通過すると，前に吸い込をれる様な感を受ける。この様に静的な刺激と動的な刺激がある が, Vogel ${ }^{19)}$ が述べている如く, 傾斜して見える様な静的な視空間と, 周囲が廻転する様な動的な 
視空間では，体平衡に及ぼす影響が異る。先に著者は視運動刺激による重心動摇への影響について 報告した ${ }^{14)}$.

動く視野の中に動かない物が見える場合，例えばオーム型の視運動刺激を与える場合，円筒との 間に固定した注視点を設け，これを固視せしめつつ円筒を廻転せしめると，固視点のない場合に比 して強いめまい感を生じることが報告されている77.

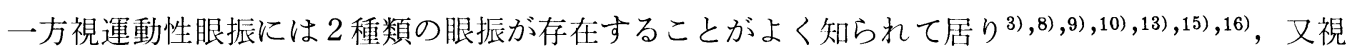
運動刺激が与えられる部位が中心窩か周辺視野かによって，生じる眼振の性状が異ることが知られ ている ${ }^{1)},{ }^{9},{ }^{17)}$. 我々は今回視運動刺激が，その加わる網膜上の位置の差により，重心動摇にどの様 に影響するかを研究することにより，視運動峃間での体平衡の様相を検討したので報告する.

\section{実 験 方 法}

実験装置. 永島社製ユンク型視運動眼振誘発 装置 OK-I-M型の, 投影器の直下にアニマ社製 重心測定装置1800型を置いた。視運動線条を, 以下の 4 条件で一定にする為, 投影器のレンズ 部を除さ，一周12本の縦格子を有する金属门筒

に変光, 単フィラメント型光源ランプがその中 央に来る様にした. かくして巾約 $5^{\circ}$ の格子の 影が縱縞としてスクリーン上に投影されること になる、投影器の周りに，先に著者の報告した 視野分離:装置 ${ }^{16)}$ (図 1) を付し, 視運動刺激の

PHOTO

TRANSISTOR

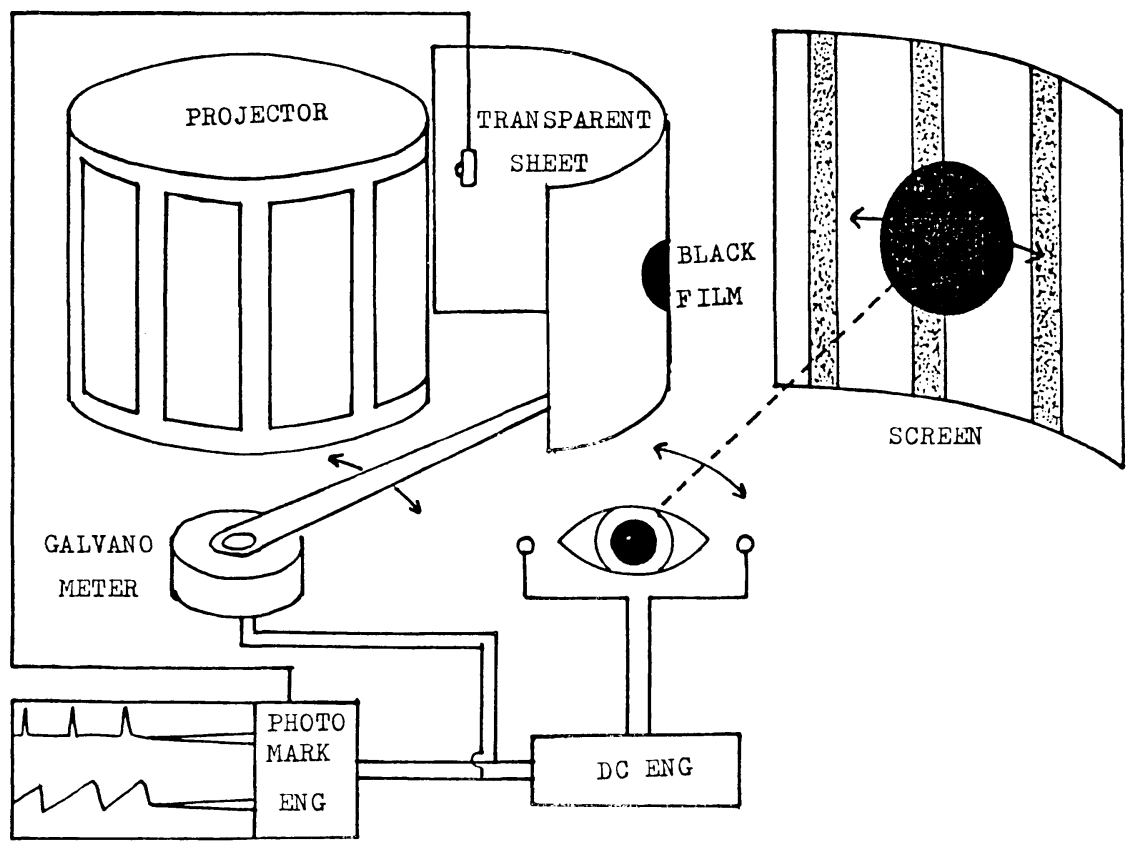

図 1 視野分離装置

ユンク型視運動刺激装置の投影器の周囲を透明円筒で囲み, 円筒上に目的に応 じた黒色不透明フイルムを貼付する（中心暗点を検討する場合は円船を正面中央 に貼る). この透明円筒を DC-ENG の出力で駆動し, 眼球と同方向に同角度で動 く様にすると, 目的に叶った部分への線条投射の欠損が生じ，この欠損部が眼の 動きと共に移動するので，目的に叶った視野欠損を作ることが出来る. 
与えられる網膜の部位を, 目的に合わせて選べ る様にした. 回転視野中の固視点を作るために は, スクリーン埋め込又の赤色発光ダイオード を点燈した。

実験条件, 実験は次の 4 条作下で行った。

1. 通常の全視野刺激.

2. 周辺視野のみの刺激, これには更に 2 つの 条件を設定した。

a . 注視性視線条件, b. 凝視性視線条件.

3. 固視点設置全視野刺激

被検者を投影器の直下に置いた重心動摇計上 に，スクリーン中央に向って閉脚して直立せし め, 爪先も閉じさせた。刺激中は頭部を正面に 向って真直ぐに保ち, 頭部, 軀幹を迴旋させら れない様努めさせたが，特に頭部，肩などを固 定することは行っていない. 視運動性刺激は等 角加速法を用い, $1^{\circ} / \mathrm{sec}^{2}$ の加速度で, 停止より $120^{\circ} / \mathrm{sec}$ 迄加速し, $120^{\circ} / \mathrm{sec}$ に達したら投影器 の光を消し，暗所で正面視を保たせた.

1. 全視野刺激, 視野分離装置 ${ }^{16)}$ の透明板上 に何らの不透明板を貼付せず，金属格子像がそ のまつスクリーン上に投影される様にした．被 検者は眼前を横切る格子像を一つづつ目で追う

\section{結}

4 条件の視運動性刺激による重心動摇の変化 を，誘発された眼振と共沉部録したが，

1. 全視野刺激 : 刺激開始後, 既報告 ${ }^{14)}$ の如 く偏倚の 2 相性を示した。即ち視運動刺激速の 未だ遅い期間は, 反回転側に次第に偏倚して行 くが，視運動速が速くなるに従って重心偏倚の 方向が逆転し，回転方向に偏倚して行く様にな る. この際の偏倚量, 振巾, 波数を, 反回転方 向に偏った相と回転方向に偏った相とで比較す ると，後者の方がいずれも大きい（図 2 ). こ の際視運動性眼振は, 図 2 下段で見られる様に 活発に発来している.

2. 周辺視野刺激

a . 注視性の場合, 視運動刺激開始と共に, 刺激速が遅い間から振门, 波数共に増大しつつ
様命ぜられた。

$2 \mathrm{a}$, 注視型周辺視野刺激, 周辺視野のみを 刺激する目的で, 視野分離装置の透明円筒正面 中央に, 視角 $40^{\circ}$ の影を作る大ささの黑色门盤 を貼付した（図 1).この影は眼球運動に際し 眼球と同方向に同じ角度だけ動くので, 径 $40^{\circ}$ の中心暗点が出来ることになり, 中心简より $20^{\circ}$ 以遠の周辺視野のみに視運動刺激が負荷さ れることになる. 被検者はこの様にして投影さ れた周辺視野の線条を眼で追うのであるが, 線 条を直視すると目標の線条が円艋の影で覆われ て見充なくなるので, 格子像を視野の周辺で捉 えつつ眼で追うことになる.

$2 \mathrm{~b}$, 凝視型周辺視野刺激, 刺激は注視型の 場合と全く同じ条件で与えられるが，被検者は 視野を横切って行く線条を意識的に追う様なこ とはせず，たぶ正面をぼんやりと直視しつつ直 立の姿勢を保つ.

3. 固視点設置全視野刺激, 視運動刺激装置 の中央に設置してある視角約 $0.3^{\circ}$ の赤色発光 ダイオードを点燈し，これを固視せしめつつ通 常の企視野視運動刺激を与兄た。

\section{果}

回転方向に向う偏倚を示し，全視野刺激で見ら れた反回転方向の偏倚を来さず，従って偏倚の 2 相性を認めなかった（図 3 ). 被検者は周辺 視野で動く線条に視線を移そうとすると, 目標 とした線条が視野分離装置の黑色円艋の影によ り被われて見えなくなるので, 周辺視野に目標 を捉えつつ線条を追うのであるが，多くは特に 練習することなく，図 3 で見られる如き良好な 視運動性眼振が誘発された. しかし眼振誘発は, 全視野刺激に比べると明かに劣っていた（図 2 , 3 ).

b. 凝視性の場合, この場合も偏倚の 2 相性 は見られず，低速刺激時から回転方向にのみ重 心の偏倚が見られた. 振巾, 波数も注視性条件 下と同様に增加している（図 4 ）。本条件下で 
視運動性刺激による重心偏倚 左回り $1 \% \mathrm{sec}^{2} 0^{\circ} \sim 120 \% \mathrm{sec}$

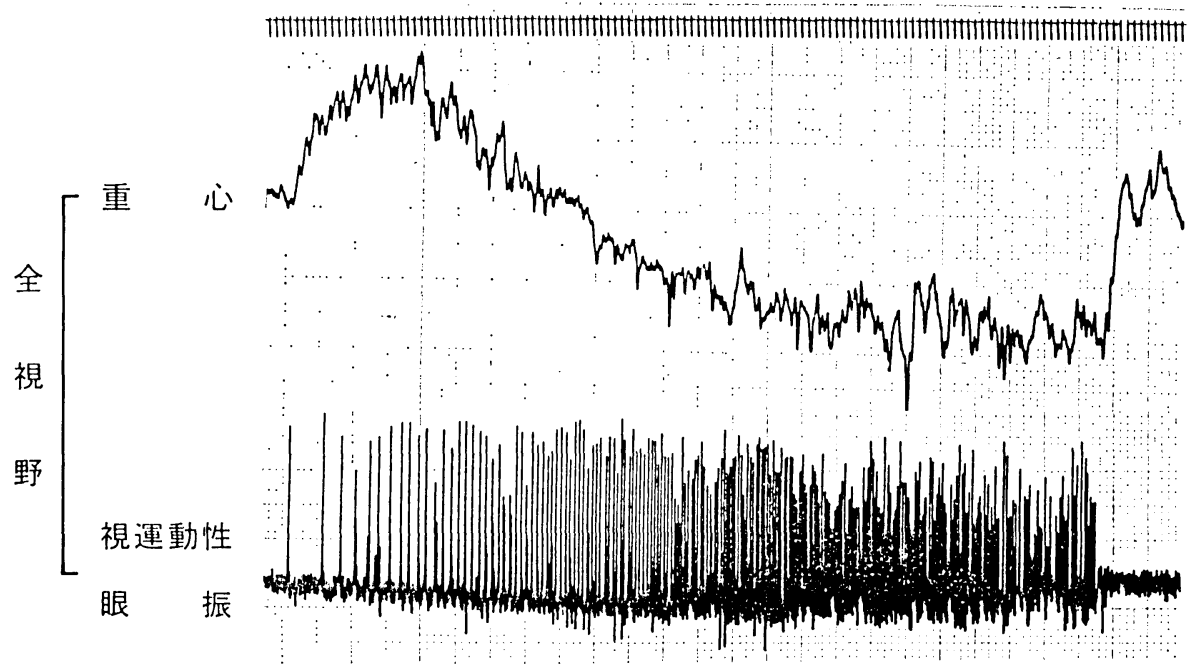

図 2 全視野刺激時の視運動性眼振と重心動摇

上が重心動摇，下が視運動性眼振速度波形を示す．各々上方が右方，下方が左方を示す. 刺激は左蚍転, 等角加速度刺激で, 停止より $1 \% \mathrm{sec}^{2}$ で $120^{\circ} / \mathrm{sec}$ 迄加速した. 眼振の誘発 は極めて良好である. 重心は初期の低速刺激時に反回転方向（右）に，後半の高速回転時に は回転方向（左）に偏倚して居り, 後者の相で振巾, 波数が増大していることが判る.

周辺視野OK 刺湤之重心偏倚 左回り $1 \% \mathrm{sec}^{2} 0 \%$ ～120\% sec

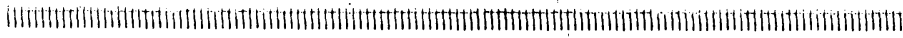

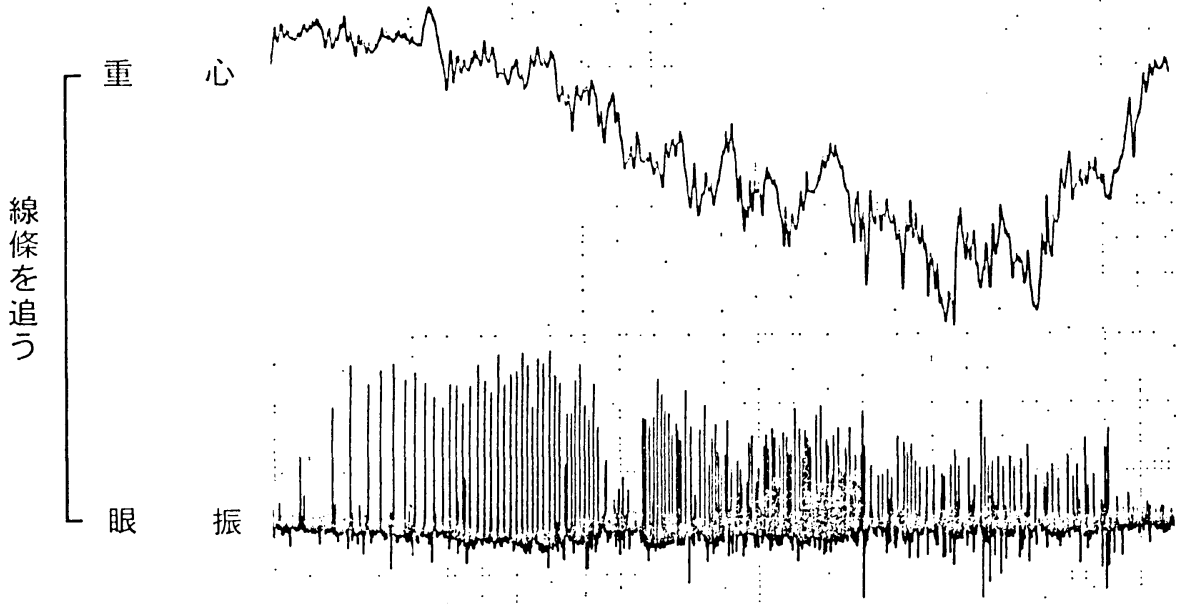

図 3 注視性周辺視野刺激時の視運動性眼振と重心動摇

曲線の順番，刺激の条件は図 2 の場合と同じである．視野分離装置で径 $40^{\circ}$ の中心暗 点を人工的作ってある. 被検者は動く線条群を周辺視野で捉えて追従している. 従っ て眼振の誘発は比較的良好である。しかし全視野刺激のそれには劣っていることは図 2 との比較で明かである. 重心は初期の低速刺激時から回転方向（左）にのみ偏倚し，偏 倚の 2 相性は認められない. 重心動摇は振巾, 波数とも増大は初期上り認められる. 
周辺視野OK 刺激亡重心偏倚 左回り $1 \% \mathrm{sec}^{2} \quad 0 \sim 120 \% \mathrm{sec}$

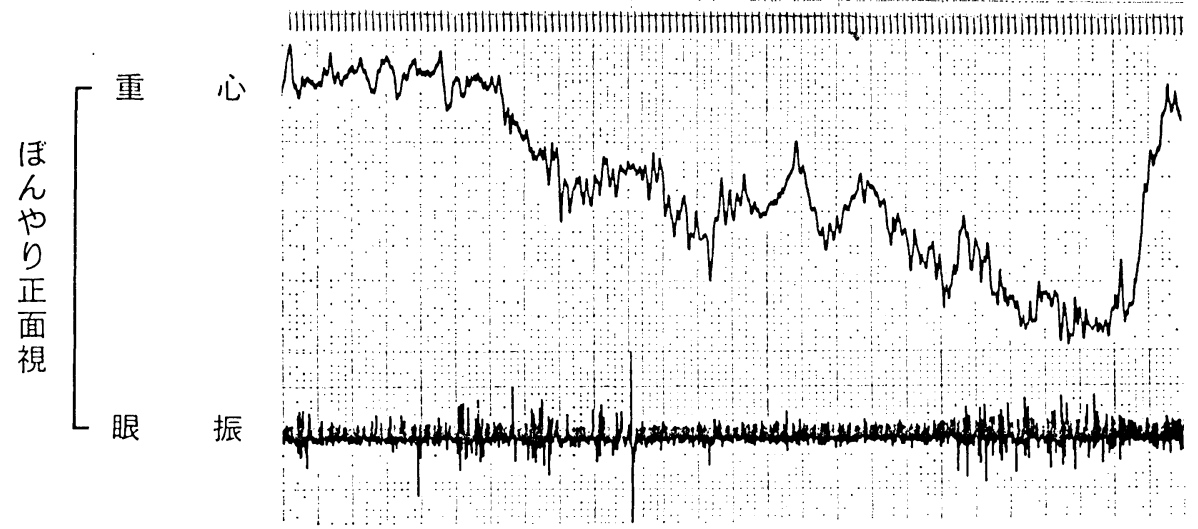

図 4 凝視性周辺視野刺激時の視運動性眼振と重心動摇

曲線の順番，刺激の条件，中心暗点共に図 3 の場合と同様である，被検者はたぶ正面 を漠然と眺めて居り，特に一点を固視する様なことはしない。その結果眼振は殆ど生じ

ていない。重心は注視性条件の時と同じく，初期の低速刺激時から回転方向（左）にの

又偏倚し， 2 相性を示さない. 動摇の増加が初期より垫められるのは図 3 と同様である.

視運動性刺激による重心偏倚 左回り $1 \% \mathrm{sec}^{2} 0 \% 120 \% \mathrm{sec}$

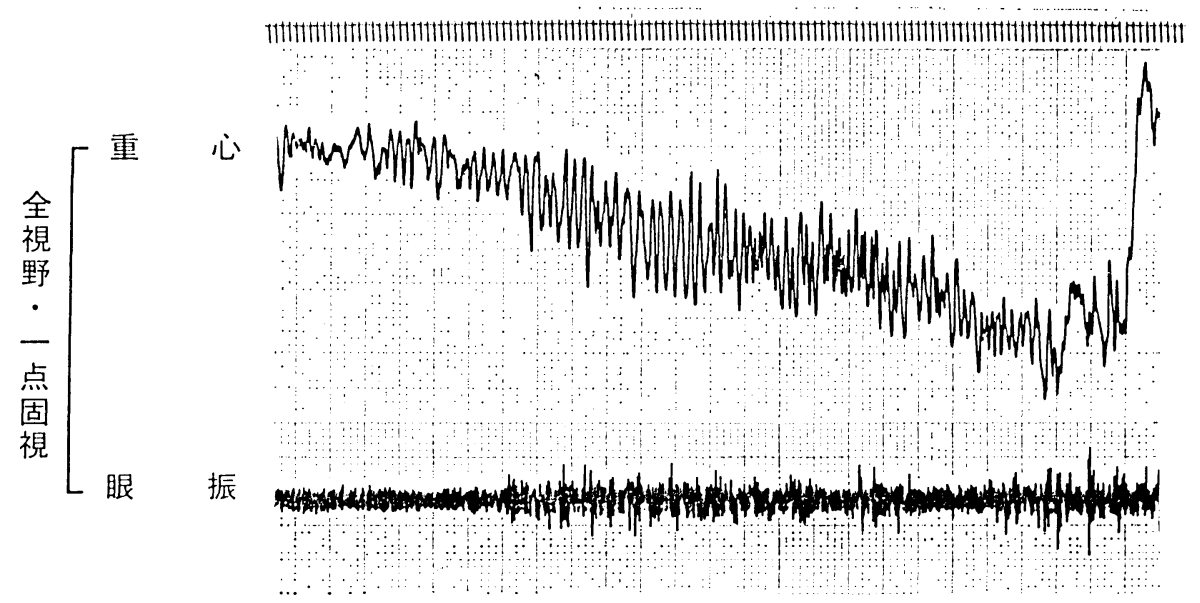

図 5 固視点設置全視野刺激時の視運動性眼振と重心動摇

曲線の順番，刺激の条件は図 2 の場合と全く同様である.たぶ刺激装置のスクリーン 上の, 視線の高さ中央に発光ダイオードを埋め込み点登し, これを固視せしめつつ刺激 を加えた. 眼球運動はこの固視の為に強く抑えられ, 眼振は全く生じていない. 重心は 初期より回転方向（左）にのみ偏倚し，2 相性は認められなかった。重心動摇は初期よ

り著明に増強し特に振门で著しかった。

は視野分離装置の為, 径 $40^{\circ}$ の中心暗点が生じ, 被検者の正面には何らの線条も投射されないの
で, 被検者は特に仮定の一点を固視する様なこ とはなく，正面を漠然と見つめる様に命ぜられ 
る. その結果, 図 4 下段に見られる如く, 眼振 は殆ど生じていない，従って線条の像は周辺網 膜上を滑っていくことになる.

即ち周辺視野刺激では注視性でも凝視性でも, 換言すれば眼振誘発の良否に係らず，常に回転 方向への偏倚のみが見られ，偏倚の 2 相性は認 められなかった。

3. 固視点設置全視野刺激, この場合も偏倚 の 2 相性は見られず，刺激速の遅い刺激初期よ り回転方向にのみ偏倚を示した（図 5 ). 振巾,

\section{考}

人体の平衡は視器, 前庭, 自己受容器の 3 者 からの情報に基き，空間内での正しい定位を得 ることにより保たれている．即ちWitkin ${ }^{20)} の$ 言う如く，空間中での正確な定位の為には周囲 の正確な認識が必須である，従って異常な視覚 情報は空間内の定位を䛊らせ，めまい感を招来 し，体平衡に破綻を生ぜしめる。新潟地震によ り傾いた建物内に住んでいる人が，めまいを 感じることについて 北原 ${ }^{12)}$ が報告している如 く, 傾斜空間内では, 視覚と他の 2 感覚の間に 解離が生じ, 違和感, めまい感を生じるのみな らず，姿勢にも影響が生じて来る，第17回前庭 研究会は, 地震直後の新潟で行われ, 会場は地 震で傾いた東映ホテルであったが，参加者の殆 どが建物に入ると，傾いている方向である左手 奥へ引き込まれる感じを受けると異口同音に言 っていた，又著者もピサの斜塔に登った時，塔 の外周に設けられた螺旋階段を登るに際し, あ る時は登り難く，ある時は登っているにも係ら ず前方へ引かれる感を受けたが，これも傾斜空 間での異和感に基くものであろら.

以上は静的視空間が及ぼす身体平衡に対する 影響であるが，Vogel ${ }^{19)}$ が述べている様に， 動的視覚が体平衡に及ぼす影響は, 静的視空間 のそれとは異っている．例えば日常よく経験す ることであるが，隣に此っていた列本が動き出 すと, あたかも自分の乗っている列車が発車し たかの様な錯覚を生じるが，この時の連動覚を
波数の増大, 特に振巾のそれは著しく, めまい 感も時に生じ，この条件下では体平衡に破綻を 来していることが示唆され, 視運動刺激時, 才 トゴニオメータを設置すると，より激しいめま (感を招来する事実と息一致した。 眼振に関し ては, 被検者が発光ダイオードを強く固視する 為, 図 5 の下段に見られる如く, 眼振は全く生 じていない、即ち投射された線条の像は, 被検 者の中心窝を含めた全網膜の上を，刺激速と同 じ速さで滑走していることになる.

\section{按}

伴うめまい感覚は，傾斜空間での異和感とは別 種のものの様である. Fischer ${ }^{6)}$ は視空間の回転 により, 反対方向に自己回転感を生じると共に, 体の回転方向への偏倚が生じると述べており， 柳原 ${ }^{4)}$ は視運動性刺激が体平衡に及ぼす影響を， 足踏検查を用いて定量的に検討し，回転方向へ の体軸回旋，移動を報告した．著者 ${ }^{14)}$ は重心 動摇を指標として，視運動性刺激が体平衡に及 ぼす影響を定量的に測定し，等角加速度視運動 刺激を加えた場合，重心が 2 相性の偏倚を示す ことを見出した。即ち回転初期の低速度刺激時 には反回転方向へ重心が偏倚するが，刺激速度 が增すと偏倚方向が逆転し，回転方向への偏倚 を示す 2 相性を認めた。更に觔加速度を 1 \% $\sec ^{2}$ から $6 \% \mathrm{sec}^{2}$ の間に種々に変えて検討し, いずれの角加速度においても同様の 2 相性のあ ることを確めた，更には $10^{\circ} / \mathrm{sec} \sim 90^{\circ} / \mathrm{sec}$ の等 速視運動性刺激を加えて検討し，低速刺激では 反回転方向に，高速刺激では回転方向に偏倚す ると絬論つけた. 又両偏倚相の境の速度は約 $45^{\circ} / \mathrm{sec}$ であると報告した. 即ち視運動刺激に

より生ずる重心偏倚の方向を決定するのは, 廻 転刺激での前庭反応の 2 相性 ${ }^{7)}$ が，廻転の角加 速度の大小に係っているのと異り, 視運動刺激 の件速度の大きさによるのであり，角加速度と は無関係であることを見出している，又反回転 側への偏倚を示す相での重心動摇は, 動摇振巾, 動摇波数ともそう大きくなく，周囲が静止して 
いる時の動摇と大差がないのに反して，回転方 向に偏倚する相では, 動摇の振门も波数も著明 に増加していることを見出し，反回転方向偏倚 相では平衡が保たれた相で，その偏倚は防禦的 なものであるのに反し，回転方向偏倚相では平 衡は失われて居り, 視空間の回転に引かれて同 方向に偏倚したものと結論, 福田 ${ }^{7)}$ が前庭刺激 の強弱による反応の 2 相性より結論した平衡の 協応, 破綻の考えと一致し, 反回転偏倚の相を 協灾の相と考兄, 回転方向偏倚の相を福田 ${ }^{7}$, 柳原 ${ }^{21)}$ が述べた如く破綻の相であると考光た。

眼球運動速について考えると, 動く目標を目 で追い掛け得る最高の速度は, $30^{\circ} / \mathrm{sec}$ と言わ れ, 視運動刺激においての正確な視標追従の限

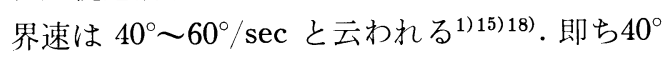
$\sim 60^{\circ} / \mathrm{sec}$ の速度を越えて速く外界が迴り出す と, 眼球が追従出来ず遅れ出すので, 外界の像 は網膜上の一定の位置に留り得ず, 視線の遅れ る方向に滑り始める. しかもこの滑りは外界の 速度が速くなるほど顕著になる。つまり外界が 速く動くほど，網膜上の外界像の滑走が大にな り，外界がぼやけて見元，Witkin ${ }^{20)}$ の指摘する 如く空間内での正確な定位が出来難くなる。外 界が $40^{\circ} \sim 60^{\circ} / \mathrm{sec}$ 以下の速度で動く時は，そ の中の一定の目標を視線即ち中心简で捉えつつ 正確に追従し得るので, 全網膜上に結ばれた外 界像全体は, 網膜上の夫々の点に固定されたま まで滑走することがなく，外界の認識が正確に 保たれるので, 空間内の定位もまた正確に保た れる.この事が低速刺激では平衡が保たれ, 高 速度では平衡破綻が生じることの主因と考兄ら れる。

Fischer が述べた如く視運動刺激の線条群と 目との間に固定点を設け，その点を見つめつつ 視運動刺激を与えると, 固視点のない場合に比 し遙かに強いめまいを生じる。福田 ${ }^{7)}$ は額带に 細い棒を前方に向けて固定し，その先に小さい 鏡を付けたものをオトゴニオメータと称し，そ の鏡にらつる被検者の目を固視点として用いた。 このオトゴニオ装着下で足踏検査を行い, 装着
時は非装着時に比しめまいが強く感じられるの みならず，回転，移動が遙かに大さいことを 亦した. 著者もバラニー型円筒で視運動刺激を 与えた時の頭部の動きと傾きを，頭部加速度 計により測定したが，固視点のない場合は低速 視運動刺激では反回転方向に, 高速刺激時には 回転方向への頭部の傾斜を認め, 重心偏倚と同 様に頭部の傾斜にも2 相性のある事を見出した が，円筒との間に固定点を設け，これを固視し つつ刺激を加えた場合にはこの 2 相性は認めら れず，視運動性刺激速の高低に係らず常に回転 方向へのみ偏倚する事を見出した ${ }^{14)}$.この様な 固視点がある場合, 被検者の視線はこの点に固 定され，視運動刺激は眼振を誘発し得ない。従 って網膜上の刺激線条の像は一定の箇所に留る ことなく, 網膜上を視線が遅れる方向へ滑って 行くことになる．この網膜上の像の滑りは，刺 激速が大なほど大さくなることは論をまたない。

一方視運動性眼振には 2 種類あることが知ら れている3 $\left.\left.\left.{ }^{3)}, 8\right), 10\right), 11\right)$. 又視運動性腿振は中心窩の 又ならず周辺視野の刺激のみでも誘発されるこ

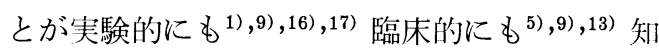
られている，著者は視野分離装置を工夫し，中 心简, 傍中心简 ${ }^{17)}$, 周辺視野を独立に刺激して 視運動性眼振を誘発し, 網膜の各箇所が視運動 性眼振誘発に果す役割と, 誘発された眼振の性 状について検討したが ${ }^{16), 17)}$, 中心窩性眼振は高 速では誘発され難いが，低速では充分誘発され， その緩徐相速は視標速と一致しており，その振 燙野は緩徐相側であり, 開始や方向変換は緩徐 相で行われ，急速相から緩徐相への変換点では 波形が鈍る傾向があるのに比し，周辺視野眼振 は比較的高速迄誘発され, 典型的な鋸歯状波で あるが, 緩徐相速は低速刺激時から既に視標速 より遅い。その振湦野は急速相側であり, 急 速相で始まったり方向変換する傾向を有するな ど, 中心窝性眼振と周辺視野眼振では，その性 状が鏡像的であることを見出している ${ }^{16)}$. 又視 運動性眼振誘発には中心より視角 $30^{\circ}$ 以内の傍 中心筒網膜が大切であることを報告した ${ }^{17)}$. こ 
の様に眼振には種類があり, 又網膜の箇所によ り眼振の性状が異ることが明かとなったが，こ の様に視運動刺激の差が誘発した眼振に差異を 生ぜしめる事実は，身体平衡に与える影響にも 差のある可能性を示唆する.

この様に各種視運動性刺激による身体平衡へ の影響が本研究では, 重心動摇の面より検討さ れた. 全視野刺激に関しては, 前回の研究では オーム型により刺激が行われ ${ }^{14)}$, 今回の実験で はユンク型刺激装置が用いられたが，共に重心 偏倚の 2 相性が認められ，刺激装置の差による 本質的な違いは見られなかった。即ち低速度刺 激では反回転方向に，惉速刺激では回転方向へ の偏倚を示したが, 前者の相では動摇の振巾も 波数もさしたる増大を示さず，この相では視運 動空間内で依然身体平衡が保たれていることを 示唆している. しかし後者の相では明かに動摇 が増大しており，体平衡が破綻を来した状態で あることを示している. 前者の相では視標の速 度の大きさを考えると, 眼による追従は正しく 行われており，外界像は網膜上に固定されてい るものと推定される. しかし後者の相では指標 速は眼球追従の適応限界を越えており, 網膜上 での外界像のずれが生じていることは明かであ り，そのずれの程度は刺激速が増すほど大とな る.

周辺視野刺激においては，注視性条件でも凝 視性条件でも共に重心偏倚の 2 相性を示すこと なく，低速度刺激時でも回転方向へ重心が偏倚 しており, 又重心動摇においても振巾, 波数と もに増加しており，体平衡が破綻を来している ことが咞われる.この様に重心動摇に対する影 響には注視性，凝視性の差は殆ど認められない が，誘発視運動性眼振には大差が見られ，注視 性条件では眼振の誘発が良好であるが，凝視性 条件では眼振の発来が殆ど認められていない。 従って後者の条件下では, 周辺網膜上での線条 像のずれ，滑走がおこっていることは明瞭であ る. 周辺網膜が視運動性眼振誘発に及淁す影響 については，先に述べた如く実験的にも中心暗
点症例など臨床的にも多くの報告がなされてい るが，これらに共通した結論は，周辺視野は眼 振誘発には不可欠の部位であるとしており, 中 には眼振誘発の主役を演ずるとするものすらあ る.しかしこれらの報告の多くは ENG 上で概 観しての定性的な結論であり，各波形について の定量的な検討が行われたものではない.著者 が視野分離装置を用いて眼振を誘発した所, 既 に述べた如く, 周辺視野刺激では典型的な鋸歯 状波を発来せしめるので, 一見誘発が良好であ るかの如く見えるが，眼球速の面より見ると， 眼振緩徐相速は低速度刺激時から既に視標速よ り遅く, 視標に対する視線の遅れが見られる. 即ち本研究に打いて, 注視性条件下では良好な 周辺視野眼振が誘発されているが，眼球速度の 面から見ると, 視標速に比し眼球速が常に遅い。 換言すれば，眼振が良く誘発されている時でも， 外界の刺激線条像が，網膜上では一点に留らず 滑走していることになる.このことは図 3 の注 視性.周辺視野眼振と困 2 の全視野性眼振とを比 較すれば, 容易に首肯し得る所である.この様 に周辺視野刺激では注視性でも凝視性でも眼振 発来の良否に係らず，網膜上で線条の滑りが生 じているが，滑りの程度は図 $3 ， 4$ 下段より明 かな如く又 Honrubia ${ }^{8)}$ の示した如く凝視性で は注視性に比し, 眼振緩徐相速が遅いので, 凝 視性においてより大である.しかし視運動刺激 に対する注意の払い方では前者注視性の方が遙 かに大であるので, 滑りの大小がこれに相殺さ れ，重心動摇に及ぼす影響に大差を見ないので あろら・

ユンク型視運動刺激装置の, 線条が投影され るスクリーン上に固視点を設け，この点を固視 せしめつつ刺激を与えた場合, 眼球運動は固視 により強く抑えられるので, 眼振は全く生じな い. 従って刺激線条の像は, 網膜上を滑ること になる，この場合線条像の滑りは，視線固定の 為最も大である上, 周辺視野刺激の時と異り, 中心䈑を含む全網膜に互って滑りが生じている ため, 更に強い刺激として作用する.しかも固 
視点が線条の投影されるスクリーン上にあり， 視線の焦点がスクリーン上に結ばれているため, 固視点が目とスクリーン間にある場合に比して, 網膜上の線条像がより明瞭であるので, 刺激と しては更に強いものとなると考兄られる。その 為か, 重心動摇の振门, 波数共に最も顕著な増 強を示し, 全視野刺激時後半や周辺視野刺激時 の重心動摇よりも著しい。この事実は，視運動 刺激を与える時，目と刺激線条の間に固視点を 設けると，固視点のない場合に比し，遙かに強 いめまい感を生じるとした Fischer ${ }^{6)}$ の報告や, 足踏検查で偏倚が 2 倍以上に增加することを示 した柳原 ${ }^{21)}$ ，福田 ${ }^{7)}$ の報告と軌を一つにしてお り, 重心動摇の面でも固視点の設定は, 視運動 刺激の影響を增大せしめることがホさされた。

この様にして生じた網膜上での外界像の滑り の為, 被検者は外界の状態の川しい認識が得ら れなくなり，空間内での定位の婄認が生じ，め まいや偏倚が生じるものと推察される.このめ まいがいわゆる cricular vection である. バレ ーダンサーは回転する歭，一笘を注視すること により，頭部を出来るだけ一定方向に向く様に 保ち，極限に達した歭素速く頭部を 1 回転させ て旧方向に向わす運動を，各回転ごとに絽り返
すが，熟練した人ほどすばやく且つリズミカル にこの運動を行う. 回転中頭部の向う方向を一 定に保つことは，一定の目標を注視するのを援 け，外界像が網膜上で流れることを防ぎ，空間 内定位を保つのに役立ち，素速く頭部を一回転 することは, 頭部回転に基く外界像の流れの時 間を短くすることで，定位衰失の時間を短くし， 平衡を保つに役立っていると思われる.

全視野刺激の高速時, 周辺視野刺激, 固視点 設置時のいずれの場合でも，眼振誘発の良否に 係らず，重心は回転方向への偏倚を示す。この 回転方向偏倚時に共通して認められるのは網膜 上での外界像の滑りである.この滑りが先に度 々述べた如く外界の状態の正しい認識を不可能 とし，空間内での定位の失認を生ぜしめ，体平 衡が乱され，その結果外界の回転に引かれて回 転方向に偏倚して行ったものと考兄られる.こ れらの場合で重心動摇がその振巾，波数共に刺 激前や反回転方向偏倚を示す低速刺激時に比し 增大しており，これらの場合では体平衡の乱れ が生じていることを示唆している.

この様に視運動刺激時めまい感, 体平衡失調, 回転方向への重心偏倚, 網膜上の外界の滑りの 間に一定の関係のあることが明かにされた。

\section{結}

\section{論}

各種視運動性刺激の体平衡に及ぼす影響を重心動摇の面より検討した。用いた刺激は，全視野視 運動性刺激, 注視性周辺視野刺激, 凝視性周辺視野刺激, 周視点設置全視野刺激の 4 種であり, そ の結果次の絬論を得た。

1. 全視野刺激では㛶報告の如く，低速刺激では反回転方向に，䯩速刺激では回転方向に重心の偏 倚を示した。前者の相では動摇はそれ程大でなく, 後者の相では振巾, 波数共に增大していた. 上記 2 相の内前者は協応の，後者は破綻の相と考えられた.

2. 注視性周辺視野刺激では, 重心偏倚の 2 相性を示さず, 低速刺激時でも回転方向への偏倚を示 し，重心動摇も増大していた。眼振誘発は比較的良好であった。

3. 凝視性周辺視野刺激でも重心偏倚の 2 相性は認めず, 腿振は殆ど誘発されなかったが, 低速刺 激でも回転方向への偏倚を示し，重心動摇は増大していた。

4. 従って周辺視野刺激では, 眼张誘発の良否に関係なく, 问転方向に偏倚し, 重心動摇は增大し た.

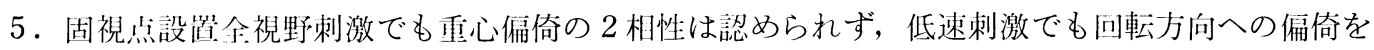
示し，重心動摇の増大は著しかった．特に振巾の増加は顕著である. 
6. 全視野低速刺激時以外の場合，即ち回転方向への偏倚を示す場合に共通な点は，視標運動に対 する眼球追従の遅れなどに基く，外界像の網膜上での滑りである.

7. 網膜上での外界像の滑りの為, 空間内定位の失認が生じ, その為体平衡に失調を来し, 廻転す る外界に引かれて同側へ偏倚するものと考えられた。

\section{参 考 文 献}

1）浅野 登, 他: 視性眼振に扩ける macular vision と peripheral vision についての一考察. Equilibrium Res. 24 : 120-121, 1963.

2) Aschan, G. et al. : Nystagmography. Acta Otolaryng. Stockh Suppl 127 : 1-103, 1955.

3) Braak Ter, G.: Untersuchung über optokinetischen Nystagmus. Arch. Neel. Physiol., 21 : 309376, 1936.

4) Dodge, R. : Five type of eye movements in the horizontal plane of the field of regard. Am. J. Physiol., 8 : 307-329, 1903.

5) Dodge, R. and Fox, J.C.: Optic nystagmus. Arch. Neurol. Psychiat., (Chic.) 20:812-823, 1928.

6) Fischer, M. H. and Veits, C. : Über optokinetische ausgelöste Körperreflexe beim Menschen. Pfluger. Arch. Ges. Physiol. 219 : 579-587, 1927.

8）福田 精: 運動と平衡の反射生理, 医学書院, 1947.

8) Honrubia, V. et al.: Experimental studies on optokinetic nystagmus. II. Normal humans. Acta Oto-laryng. Stokh. 65 : 441-448, 1939.

9) Hood, J. D. : Observations upon the neurological mechanisum of optokinetic nystagmus with especial reference to the contribution of peripheral vision. Acta Oto-laryng. Stokh. 63 : 208215, 1967.

10) Jung, R und Mittermaier, R.: Zur objectiven Registrierung und Analyse versiedener Nystagmusformen: vestibulare, optokinetische und spontaner Nystagmus in ihren Wechselbeziehungen. Arch. Ohr usw Heilk. Berlin. 146 : 410432, 1939.
11）水越鉄理：視性眼振の生理補遗(1). 日耳鼻. 64 : 23-49, 1961.

12）北原正章，他：傾斜室に怙计る眩暈と平衡.耳鼻 臨床 58: 145-151, 1965.

13）仲野紶介：固視パターンによる視運動性眼振の研 究. 耳鼻臨床. $70: 147-176,1977$.

14）三好豊二: 視機刺激の重心動摇に及ぼす影響.耳 鼻臨床. 61 : 1620-1641， 1968.

15) Miyoshi, T. and Pfaltz, C.R.: Studies on the correlation between optokinetic stimulus and induced nystagmus. ORL 35: 350-362, 1973.

16) Miyoshi, T. et al. : Foveal and peripheral vision in optokinetic nystagmus. Vestibular mechanismus in health and disease (Hood Ed.) Academic Press London 1978.

17）三好豊二，他 : 視野各部の視運動性眼振に及ぼす 影響: Equilibrium Res., 38 : 45-49, 1979.

18）玉王 彰, 他: 視標追跡運動における速度, 振巾, 周波数の及ぼす影響力について。 Equilibrium Res. 40 : 38 44, 1981

19) Vogel, P.: Über optokinetische Reactionsbewegungen und Scheinbewegungen. Pfluger. Archiv. Ges. Physiol. 228 : 632-643, 1931.

20) Witkin, H. A. and Wapner, S. : Visual factors in the maintenance of upright posture. Amer. J. Psychol. 63 : 31-39, 1950.

21）柳原亮一：視性運動失調並びに視性眩最の研究. 耳鼻臨床 45 : 47-55, 1952.

$$
\left(\begin{array}{l}
\text { 別刷請求先 : 三好豊二 } \\
\bar{T} 610-01 \\
\text { 国立療養所南京都病院 }
\end{array}\right)
$$

